\title{
Ventilatory and muscular assessment in healthy subjects during an activity of daily living with unsupported arm elevation
}

\author{
Avaliação ventilatória e muscular de indivíduos saudáveis durante atividade de \\ vida diária com os braços elevados e sem apoio
}

Giselle F. L. Panka', Marina M. Oliveira², Danielle C. França', Verônica F. Parreira ${ }^{3}$, Raquel R. Britto³, Marcelo Velloso³.

\begin{abstract}
Introduction: Patients with chronic obstructive pulmonary disease (COPD) report dyspnea when performing activities of daily living (ADLs) with elevated upper limbs. To elucidate the determinants of dyspnea, it is important to study the changes in the respiratory pattern of these patients and the electromyographic activity of their accessory muscles of respiration during ADLs. In the literature, there are no reports of a normative parameter, therefore it is necessary to study how these variables behave in healthy subjects. Objectives: To verify, in healthy subjects, the existence of changes in the respiratory pattern and activation of the sternocleidomastoid (SCM) muscle during an ADL with unsupported arm elevation. Methods: Thirteen male subjects, $60.57( \pm 6.42)$ years old, with normal spirometry values for age and sex, were evaluated using surface electromyography (EMG) and respiratory inductive plethysmography (RIP) collected at rest and during the activity of combing their hair with elevated and unsupported upper limbs. The data distribution was assessed using Shapiro-Wilk's test. ANOVA was used to compare the phases, and when the difference was significant $(p<0.05)$, Tukey's test was applied. Results: The RIP during the $A D L$ showed a significant increase in tidal volume, minute ventilation, respiratory frequency and mean inspiratory flow. Thoracoabdominal asynchrony was identified in percentage of asynchrony in inspiration, expiration, and Phase Angle $(p<0.05)$. The EMG showed an increase in SMC muscle recruitment $(p<0.05)$. Conclusions: Healthy subjects increased their SCM muscle activation and changed their breathing pattern when performing the ADL with unsupported arm elevation, resulting in thoracoabdominal asynchrony.
\end{abstract}

Key Words: Physical therapy; upper limbs; activities of daily living.

\section{Resumo}

Introdução: Pacientes com doença pulmonar obstrutiva crônica (DPOC) relatam dispneia quando realizam atividades da vida diária (AVD) com membros superiores (MMSS) elevados. Estudar as alterações do padrão respiratório e a atividade eletromiográfica dos músculos acessórios da respiração desses pacientes nas AVD pode contribuir para esclarecer os determinantes de dispneia. Entretanto, não se encontrou, na literatura, um padrão de normalidade, fazendo-se necessário estudar, primeiramente, o comportamento dessas variáveis em saudáveis. Objetivos: Verificar, em indivíduos saudáveis, a existência de mudanças no padrão respiratório e na ativação do músculo esternocleidomastoideo (ECM) durante a realização de uma AVD com os MMSS elevados e sem apoio. Métodos: Treze voluntários masculinos, com média de idade 60,57 (6,42) anos, com valores espirométricos normais para idade e sexo foram avaliados com eletromiografia (EMG) de superfície e pletismografia respiratória por indutância (PRI), coletadas durante o repouso e na atividade de pentear cabelos com MMSS elevados sem apoio. A distribuição dos dados foi analisada pelo teste Shapiro-Wilk. Para a comparação entre as fases avaliadas, utilizou-se ANOVA e, quando a diferença foi considerada significativa $(p<0,05)$, aplicouse o teste de Tuckey. Resultados: A PRI, durante a AVD, mostrou aumentos significativos do volume corrente, do volume minuto, da frequência respiratória e do fluxo inspiratório médio. Observou-se assincronia toracoabdominal tanto em porcentagem de assincronia na inspiração e na expiração quanto na análise do Ângulo de Fase $(p<0,05)$. A EMG mostrou aumento no recrutamento do ECM $(p<0,05)$. Conclusões: Indivíduos saudáveis apresentam maior ativação do músculo ECM e modificam o padrão respiratório durante AVD com MMSS elevados sem apoio, gerando assincronia toracoabdominal.

Palavras-chaves: Fisioterapia; membro superior; atividades cotidianas.

\section{Received: 22/04/2009 - Revised: 05/08/2009 - Accepted: 21/10/2009}

Graduate Program in Rehabilitation Sciences, Universidade Federal de Minas Gerais (UFMG), Belo Horizonte (MG), Brazil

${ }^{2}$ Physical Therapy Course, UFMG

${ }^{3}$ Physical Therapy Department, UFMG

Correspondence to: Marcelo Velloso, Departamento de Fisioterapia, UFMG, Avenida Presidente Antônio Carlos, 6627, CEP 31270-901, Belo Horizonte (MG), Brazil, e-mail: marcello.vel@gmail.com 


\section{Introduction $\because \therefore$.}

In healthy subjects ${ }^{1}$ and in patients with chronic obstructive pulmonary disease (COPD), arm elevation results in changes in the pattern of respiratory muscle recruitment and in an increase in metabolic demand, the latter being more marked in subjects with airflow obstruction ${ }^{2-9}$. This could be explained by an efficiency reduction in the respiratory mechanics, by a dual activity of shoulder girdle muscles in COPD and by an increase in dead space ${ }^{2}$.

Patients with COPD report fatigue and dyspnea when performing activities of daily living (ADLs) with unsupported arm elevation', such as combing their hair ${ }^{4}$ and brushing their teeth. In contrast, they find it less difficult to perform more demanding activities involving their legs ${ }^{1,10}$. It is likely that these patients' ability to sustain unsupported arm elevation is not determined by the endurance and strength of the shoulder girdle muscles alone. A number of studies suggest that this limitation in respiratory mechanics is influenced by arm positioning, with changes being observed in the respiratory breathing pattern and thoracoabdominal asynchrony during unsupported arm elevation ${ }^{8,10,11}$.

According to Epstein et al. ${ }^{6}$, when COPD patients sustain arm elevation, two factors become determinants of the altered respiratory pattern: lung hyperinflation and, to a small degree, diaphragm reserve strength. During inspiration due to dynamic hyperinflation, the respiratory muscles are placed in an unfavorable position of their length-tension curve, reducing the strength generation capacity ${ }^{12}$. Therefore, unsupported arm elevation may force the shoulder girdle muscles and the upper torso to participate simultaneously in the ventilatory and non-ventilatory activities ${ }^{14,6}$. Simultaneous afferent inputs and outputs of the central nervous system (CNS), responsible for the respiratory and tonic functions of these muscles, can result in a significant lack of coordination of respiratory muscle action and can result in an increase in dyspnea, with thoracoabdominal asynchrony being observed during unsupported arm exercise $^{6}$.

Based on the literature on the possible reasons for dyspnea and changes in the respiratory pattern and respiratory muscle recruitment in COPD patients during ADL with unsupported arm elevation, it is necessary to establish parameters for healthy subjects for further comparison studies involving COPD patients. The findings of these studies will contribute to the development of future interventions and/or improvements in the existing ones, providing more functional independence and, consequently, better quality of life for these individuals. Also, the findings of the present study will be used in another study, currently underway by our group, comparing the results of healthy subjects with COPD patients using the same protocol during an ADL with unsupported upper limbs. Therefore, the current data will also be part of a more comprehensive research. The aim of the present study was to assess, in healthy subjects, the breathing pattern, thoracoabdominal motion and electromyographic activity of the sternocleidomastoid (SCM) muscle at rest and during an ADL with unsupported arm elevation.

\section{Methods $: \because$.}

The Ethics Research Committee of Universidade Federal de Minas Gerais, Belo Horizonte (MG), Brazil, approved the protocol (ETIC 551/06), and all subjects gave their informed consent. The sample calculation was accomplished after a pilot study with the first ten subjects, using all respiratory pattern variables, thoracoabdominal motion and electromyography (EMG) to a power of $80 \%$ and a significance level of 0.05 (non-directional). The calculation resulted in a value of 13.8 healthy subjects. The sample consisted of 13 healthy subjects selected from the community. The inclusion criteria were: male subjects, age between 50 and 80 years, absence of bone and joint impairment in the shoulder girdle and normal lung function tests according to Brazilian standards of normality ${ }^{13}$. The exclusion criteria were: inability to maintain overhead arm elevation for the five minutes of data collection and inability to perform any of the steps determined in the protocol. A signed informed consent form was obtained from all subjects.

The subjects underwent a functional analysis of lung volume and capacity. A portable spirometer (Vitalograph $2120^{\circledR}$, Vitalograph, Buckingham, England) was used to ensure normal lung function according to the recommendations of the Brazilian Society of Pneumology ${ }^{13}$. The values of the spirometric variables were compared to predicted values according to Pereira et al. ${ }^{14}$. The breathing pattern was accessed by respiratory inductive plethysmography (RIP) based on the principle first described by Konno and Mead ${ }^{15}$, and the electromyographic activity of the SCM muscle was accessed by surface EMG.

Respiratory variables were obtained by RIP (Respitrace ${ }^{\circledR}$, Nims, Miami, FL, USA). Teflon-coated inductance coils of appropriate size were placed around the rib cage $(\mathrm{RC})$ and abdomen (AB); the upper edge of the $\mathrm{RC}$ band was placed at the level of the axilla and the $A B$ band at the level of the umbilicus. The signals were calibrated using qualitative diagnostic calibration $(\mathrm{QDC})^{16}$ during five minutes of natural breathing; this is a twostep procedure whereby the $\mathrm{RC}$ and $\mathrm{AB}$ electrical gains of the RIP amplifiers are correctly partitioned during tidal breathing and subsequently compared to the output of a spirometer to attain equivalence. The subject then breathed into a spirometer via a mouthpiece (Vitatrace, Pro Médico, Rio de Janeiro, RJ, Brazil) with the nose clipped, for 30 to $60 \mathrm{~s}$, and the electrical 
spirometer output was recorded with a computer and used to calibrate the RIP sum signal for absolute volume in $\mathrm{mL}^{17}$. The spirometer was calibrated with a one-liter syringe (Vitalograph, Ennis, Ireland). The entire procedure was performed using a computer software (RespiPanel 4.0, Nims Miami, FL, USA $)^{18,19}$ that allows a tidal volume $\left(\mathrm{V}_{\mathrm{T}}\right)$ variation $\leq 5 \%$ during calibration process.

The following variables were measured by a digital acquisition system on a breath-by-breath basis (RespiEvents ${ }^{\circledR}$, Nims, Miami, FL, USA): tidal volume $\left(\mathrm{V}_{\mathrm{T}}\right)$, respiratory frequency $(f)$, minute ventilation $\left(\mathrm{V}_{\mathrm{E}}\right)$, inspiratory time $(\mathrm{Ti})$, inspiratory duty cycle (Ti/Ttot), mean inspiratory flow $\left(\mathrm{V}_{\mathrm{T}} / \mathrm{Ti}\right), \mathrm{RC}$ motion contribution to $\mathrm{V}_{\mathrm{T}}\left(\mathrm{RC} / \mathrm{V}_{\mathrm{T}}\right)$, phase angle (PhAng; $0^{\circ}$ for complete $\mathrm{RC}-\mathrm{AB}$ synchrony and $180^{\circ}$ for complete asynchrony) ${ }^{20}$, inspiratory RC-AB synchrony (PhRIB), expiratory $\mathrm{RC}-\mathrm{AB}$ synchrony (PhREB), inspiratory and expiratory synchrony (PhRTB), variables that represent the time percentage during a respiratory cycle in which the $\mathrm{RC}$ and $\mathrm{AB}$ move in opposite directions. When the $\mathrm{RC}$ and $\mathrm{AB}$ are moving in perfect synchrony, the values are equivalent to $0 \%$, and when there is paradoxical movement, they are equivalent to $100 \%^{20}$. The contribution of abdominal motion to $\mathrm{V}_{\mathrm{T}}\left(\mathrm{AB} / \mathrm{V}_{\mathrm{T}}\right)$ was calculated as $\mathrm{AB} / \mathrm{V}_{\mathrm{T}}=100-\mathrm{RC} / \mathrm{V}_{\mathrm{T}}$.

The surface EMG device (EMG System do Brasil LTDA, São Paulo, SP, Brazil) was used to record the electromyographic activity of the SCM muscle. After the skin was cleansed, ECG bipolar surface electrodes (Mini Medi Trace 100, Kendall - LTP/ Tyco, Canada) were placed on the lower third of the left sternal portion of the SCM muscle belly. The electrodes were positioned $2.5 \mathrm{~cm}$ apart over this area ${ }^{21,22}$. The EMG signals were recorded using one of the eight channels of the biological signal acquisition system consisting of a signal conditioner with a gain of 1000, a high-pass filter of $20 \mathrm{~Hz}$, and a low-pass filter of $500 \mathrm{~Hz}$, a specific software for data acquisition and analysis (Aqdados, São José dos Campos, SP, Brazil) and a 12-bit analogto-digital converter, with a sample frequency of $2000 \mathrm{~Hz}$ for the channel and an entry band of $5 \mathrm{mV}$. The mean amplitude of the signal was estimated by its root mean square (RMS) value. In the present study, the data were normalized by rest, given that the objective was to compare the analyzed variables at rest and at different moments of an ADL with unsupported arm elevation. The subject was his own control group.

There was a simultaneous collection for the surface EMG and for the RIP data, there were two different collections. In the first collection, the data were collected with the subject in a seated position and arms resting along the body during five minutes. For the statistical analyses, the last regular minute of the RIP was considered. Next, the second data collection was conducted with the subject in a seated position and combing their hair with unsupported arm elevation for five minutes. The subjects were instructed to perform the combing movement on the top of the head, alternating both arms with the dominant hand holding the comb while the other followed the movement. The activity had to be constant and uninterrupted for the entire period and at a minimum of $90^{\circ}$ arm elevation. The last 30 seconds of the $1^{\text {st }}, 3^{\text {rd }}$ and $5^{\text {th }}$ minute were considered for analyses.

Data are reported as mean and standard deviation (SD). The data distribution for each variable was assessed using Shapiro-Wilk's test. The comparisons between the four analyzed phases (rest, $1^{\text {st }}, 3^{\text {rd }}$ and $5^{\text {th }}$ minute of exercise) were performed with ANOVA for repeated measures. When the difference was considered significant, Tukey's test was performed to identify the difference between pairs. The level of significance $(\alpha)$ was set at 0.05 for all tests. Data were analyzed with the Statistical Package for the Social Sciences software (SPSS 15.0, Chicago, IL, USA).

\section{Results $: \because$}

Demographic data of the 13 subjects are presented in Table 1 . The values for the variables during rest, $1^{\text {st }}, 3^{\text {rd }}$, and $5^{\text {th }}$ minutes of exercise with unsupported arm elevation and the respective analysis are presented in Table 2.

\section{Breathing pattern}

The $\mathrm{V}_{\mathrm{T}}$ increased significantly from the $3^{\text {rd }}$ minute; its value was $31 \%$ higher than the rest value. At the $5^{\text {th }}$ minute, a slight increase in $\mathrm{V}_{\mathrm{T}}$ was observed when compared with the $3^{\text {rd }}$ minute corresponding to a value $33 \%$ higher than rest. There was a statistically significant difference between rest and the $3^{\text {rd }}$ minute $(\mathrm{P}=0.008)$, rest and the $5^{\text {th }}$ minute $(\mathrm{P}=0.033)$ and between the $1^{\text {st }}$ and the $3^{\text {rd }}$ minute $(\mathrm{P}=0.048)$ of activity (Table 2$)$.

The $f$ increased between rest and the $1^{\text {st }}$ minute of activity, which was $21 \%$ higher than the baseline value, and then remained stable during the course of the exercise. There was a statistically significant difference between rest and the $1^{\text {st }}$ minute

Table 1. Characteristics of the 13 subjects.

\begin{tabular}{|c|c|c|c|}
\hline Variables & Mean & SD & Range \\
\hline Age (yr) & 60.6 & 6.42 & $51-71$ \\
\hline Weight (Kg) & 72.1 & 11.14 & $56-90$ \\
\hline Height (m) & 1.7 & 0.06 & $1.6-1.8$ \\
\hline $\mathrm{BMI}\left(\mathrm{Kg} / \mathrm{m}^{2}\right)$ & 25.6 & 3.63 & $19.2-30.9$ \\
\hline FVC \% pred & 105.2 & 20.41 & $86.7-162.7$ \\
\hline FEV $1 \%$ pred & 101.4 & 23.45 & 73.6-118.8 \\
\hline $\mathrm{FEV}_{1} / \mathrm{FVC}(\%)$ & 76.7 & 0.05 & $70.0-83.1$ \\
\hline
\end{tabular}

$\mathrm{SD}=$ standard deviation; $\mathrm{Kg}=\mathrm{kilogram}$; $\mathrm{m}=$ meters; $\mathrm{BMI}=$ body mass index; $\mathrm{FVC=forced} \mathrm{vital}$ capacity; $\mathrm{VEF}_{1}=$ forced expiratory volume in one second 
Table 2. The analyzed variables during rest, $1^{\text {st }}, 3^{\text {rd }}$, and $5^{\text {th }}$ minutes of exercise with unsupported arm elevation. The values of $p$, $f$ and Power of ANOVA for repeated measures are also presented.

\begin{tabular}{|c|c|c|c|c|c|c|c|}
\hline Variable & Rest & $1^{\text {st }}$ & $3^{\text {rd }}$ & $5^{\text {th }}$ & $p$ & $f$ & Power \\
\hline$V_{T}(m L)$ & 461.42 (199.08) & $530.21(205.66)$ & $603.57(254.88)^{\star} \dagger$ & $612.48(204.18)^{\star}$ & 0.010 & 4.39 & 0.83 \\
\hline$V_{F}(1 / m i n)$ & $5.82(1.64)$ & $8.41(2.66)^{\star}$ & $9.74(3.05)^{*} \dagger$ & $9.79(2.75)^{\star} \dagger$ & 0.000 & 18.48 & 0.99 \\
\hline$f(\mathrm{bpm})$ & $14.15(4.46)$ & $17.17(4.64)^{\star}$ & $17.47(5.06)^{\star}$ & $17.37(4.74)^{\star}$ & 0.001 & 6.91 & 0.96 \\
\hline $\mathrm{Ti}(\mathrm{s})$ & $1.81(0.83)$ & $1.54(0.47)$ & $1.53(0.58)$ & $1.56(0.48)$ & 0.105 & 2.27 & 0.40 \\
\hline $\mathrm{Ti} / \mathrm{Tt}$ tot & $0.37(0.04)$ & $0.40(0.05)$ & $0.40(0.04)$ & $0.41(0.04)$ & 0.103 & 2.22 & 0.51 \\
\hline $\mathrm{V}_{\mathrm{T}} / \mathrm{Ti}(\mathrm{mL} / \mathrm{s})$ & 265.71 (82.62) & $361.38(109.76)^{\star}$ & $419.62(139.67)^{*}$ & $419.52(146.26)^{*}$ & 0.001 & 11.19 & 0.99 \\
\hline$\% R C / N_{T}$ & $52.27(15.40)$ & $48.54(14.79)$ & $46.73(15.23)$ & $48.04(16.36)$ & 0.479 & 0.74 & 0.16 \\
\hline
\end{tabular}

Data expressed as mean (standard deviation). Significant difference was considered when $p<0.05$; * Statistically different in comparison to rest; $\uparrow$ Statistically different in comparison to the $11^{\text {st }}$ minute.

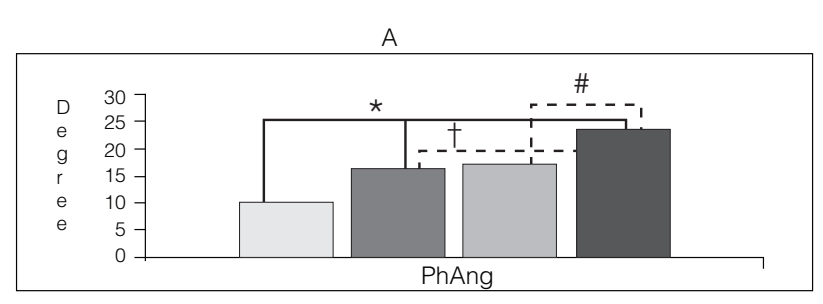

B

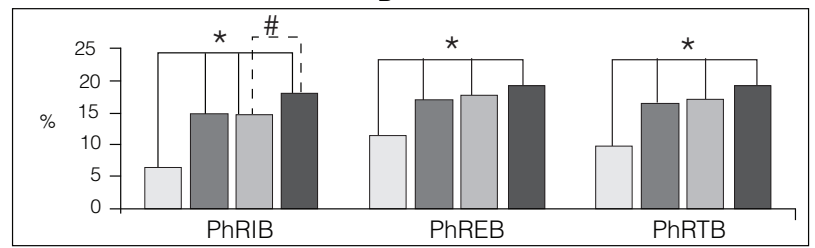

C

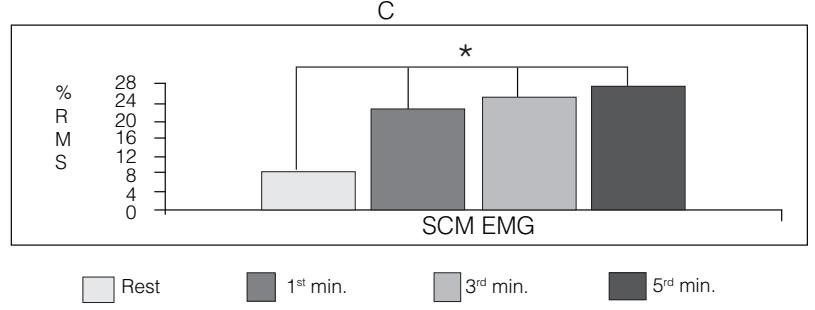

Significant difference was considered when $\mathrm{p}<0.05$;

* Statistically significant for rest; $†$ Statistically significant for the $1^{\text {st }}$ minute; \#Statistically significant for the $3^{\text {rd }}$ minute; PhAng=Phase Angle; PhRIB=inspiratory RC-AB synchrony; $\mathrm{PhREB}=$ expiratory $\mathrm{RC}-\mathrm{AB}$ synchrony; $\mathrm{PhRTB}=$ inspiratory and expiratory synchrony; $\mathrm{SCM}=$ sternocleidomastoid muscle; $\mathrm{EMG}=$ electromyography.

Figure 1. A) Comparison between PhAng during rest and during the analyzed moments of the hair-combing activity. B) Comparison between $\mathrm{PhRIB}$, PhREB and PhRTB during rest and during the analyzed moments of the hair-combing activity. C) Comparison between SCM EMG during rest and during the analyzed moments of the hair-combing activity.

$(\mathrm{P}=0.013)$, rest and the $3^{\text {rd }}$ minute $(\mathrm{P}=0.003)$ and between rest and the $5^{\text {th }}$ minute $(\mathrm{P}=0.01)$ of activity (Table 2$)$. Consequently, the changes in $f$ in the $1^{\text {st }}$ minute, in addition to the changes in $\mathrm{V}_{\mathrm{T}}$, led to a progressive increase in $\mathrm{V}_{\mathrm{E}}$ until the $3^{\text {rd }}$ minute, with a $67 \%$ higher value than rest that remained unchanged through the $5^{\text {th }}$ minute. There was a significant difference between rest and the $1^{\text {st }}$ minute $(\mathrm{p}=0.001)$, rest and the $3^{\text {rd }}$ minute $(\mathrm{p}<0.001)$, rest and the $5^{\text {th }}$ minute $(\mathrm{p}<0.001)$, and between the $1^{\text {st }}$ and the $3^{\text {rd }}$ minute $(\mathrm{p}=0.013)$ and the $1^{\text {st }}$ and the $5^{\text {th }}$ minute of exercise ( $\mathrm{p}=0.02$; Table 2$)$.

The $\mathrm{V}_{\mathrm{T}} /$ Ti presented a $36 \%$ increase in the $1^{\text {st }}$ minute when compared with rest, a $56 \%$ increase in the $3^{\text {rd }}$ minute, stabilizing in the $5^{\text {th }}$ minute of activity. There was a significant difference when comparing rest and the $1^{\text {st }}$ minute $(\mathrm{p}<0.001)$, rest and the $3^{\text {rd }}$ minute $(\mathrm{p}<0.001)$ and rest and the $5^{\text {th }}$ minute of activity $(\mathrm{p}=0.003$; Table 2).

\section{Thoracoabdominal motion}

No statistically significant difference was found for $\% \mathrm{RC} / \mathrm{V}_{\mathrm{T}}$ and for $\% \mathrm{AB} / \mathrm{V}_{\mathrm{T}}$ during the activity period, however it was observed that at rest $\% \mathrm{RC} / \mathrm{V}_{\mathrm{T}}$ was $4.54 \%$ higher than $\% \mathrm{AB} / \mathrm{V}_{\mathrm{T}}$, and that during the exercise there was a shift to $\mathrm{AB}$ in which the $\% \mathrm{AB} / \mathrm{VC}$ increased its participation by $6.54 \%$ compared with $\% \mathrm{RC} / \mathrm{V}_{\mathrm{T}}$ (Table 2). Considering the PhAng, we observed that the subjects presented a PhAng of $23.82^{\circ}$ at the end of the activity, which corresponds to a $129 \%$ increase from rest. There was a significant difference when considering rest and the $1^{\text {st }}$ minute $(\mathrm{p}=0.038)$, rest and the $5^{\text {th }}$ minute $(\mathrm{p}=0.003)$, the $1^{\text {st }}$ and the $5^{\text {th }}$ minute $(\mathrm{p}=0.045)$ and the $3^{\text {rd }}$ and the $5^{\text {th }}$ minute of exercise $(\mathrm{p}=0.026$; Figure 1 - A).

A progressive increase in PhRIB was observed during the activity, corresponding to $6.36 \%$ at rest, $14.77 \%$ in the $1^{\text {st }}$ minute, $14.59 \%$ in the $3^{\text {rd }}$ minute and $17.73 \%$ in the $5^{\text {th }}$ minute, which represents a $79 \%$ increase between rest and the end of the exercise. There was a significant difference when considering rest and the $1^{\text {st }}$ minute $(\mathrm{p}<0.001)$, rest and the $3^{\text {rd }}$ minute $(\mathrm{p}<0.001)$, rest and the $5^{\text {th }}$ minute $(\mathrm{p}<0.001)$ and the $3^{\text {rd }}$ and the $5^{\text {th }}$ minute of exercise ( $\mathrm{p}=0.034$; Figure 1 - B). Similarly, a progressive increase in PhREB was observed during the activity, corresponding to $11.63 \%$ at rest, $17.18 \%$ in the $1^{\text {st }}$ minute, $18.07 \%$ in the $3^{\text {rd }}$ minute and $19.05 \%$ in the $5^{\text {th }}$ minute, which represents a $64 \%$ increase between rest and the end of the exercise. There was a significant difference when considering rest and the $1^{\text {st }}$ minute $(\mathrm{p}=0.042)$, rest and the $3^{\text {rd }}$ minute $(0.021)$, and rest and the $5^{\text {th }}$ 
minute of exercise ( $p=0.001$; Figure 1 - B). When we consider the PhRTB, a progressive increase in synchrony between the two compartments was also observed during the activity, corresponding to $9.93 \%$ at rest, $16.61 \%$ in the $1^{\text {st }}$ minute, $17.09 \%$ in the $3^{\text {rd }}$ minute and $19.12 \%$ in the $5^{\text {th }}$ minute, which represents a $92 \%$ increase between rest and the end of the exercise. There was a statistically significant difference when considering rest and the $1^{\text {st }}$ minute $(p=0.005)$, rest and the $3^{\text {rd }}$ minute $(p=0.002)$ and rest and the $5^{\text {th }}$ minute of exercise $(p<0.001$; Figure $1-B)$.

\section{Electromyography activity}

The subjects' SCM muscle activity between rest and the activity of combing hair with unsupported arm elevation ranged in the following magnitude compared with rest: $168 \%$ RMS in the $1^{\text {st }}$ minute, $196 \%$ RMS in the $3^{\text {rd }}$ minute and $224 \%$ RMS in the $5^{\text {th }}$ minute. There was a statistically significant difference when comparing rest with the $1^{\text {st }}(p=0.005)$, the $3^{\text {rd }}(p=0.001)$ and the $5^{\text {th }}$ minute of exercise $(p=0.001$; Figure 1 - C). No correlations were found between the respiratory pattern variables, thoracoabdominal motion and electromyographic activity of the SCM muscle.

\section{Discussion $\because \therefore$.}

The main results of this study were: increased $f$ and $\mathrm{V}_{\mathrm{T}}$, followed by increased $\mathrm{V}_{\mathrm{E}}$, increased $\mathrm{V}_{\mathrm{T}} / \mathrm{Ti}$ and thoracoabdominal asynchrony demonstrated by PhAng, PhRIB, PhREB, PhRTB, and increase in SCM muscle activity during the unsupported arm elevation. In addition, a change was observed, though not statistically significant, in the predominance of the contribution of the $R C$ and $A B$ to $V_{T^{*}}$ There was a significant increase in $\mathrm{V}_{\mathrm{T}}$, followed by a slightly increased $f$, resulting in a significant increase in $\mathrm{V}_{\mathrm{E}}$ during the activity time with unsupported arm elevation. The $\mathrm{V}_{\mathrm{T}}$ and $\mathrm{V}_{\mathrm{E}}$ absolute values during rest were comparable with those reported by Tobin et al. ${ }^{23}$ using RIP in healthy subjects in the supine position. However, when comparing breathing patterns from different studies, body posture must also be taken into account ${ }^{23,24}$.

In the sitting position, Couser, Martinez and Celli ${ }^{3}$ and Baarends et al. ${ }^{2}$ measured $V_{\mathrm{E}}$ and $\mathrm{V}_{\mathrm{T}}$ using other methods, and the results were markedly higher than those recorded for healthy subjects during rest in the present study. This difference probably relates to direct measuring techniques which employ breathing through a mouthpiece with the nose clipped ${ }^{23}$. As a consequence of the small variation in $f(21 \%)$ and especially in $\mathrm{V}_{\mathrm{T}}$ in the $3^{\text {rd }}$ minute $(31 \%)$, there was a progressive increase in $V_{E}$ until the $3^{\text {rd }}$ minute, achieving $67 \%$ of the rest value, remaining stable until the $5^{\text {th }}$ minute. These results are partially comparable with those reported by Couser, Martinez and Celli ${ }^{3}$ and by Baarends et $\mathrm{al}^{2}$, who analyzed healthy subjects with static elevated arms for 2 minutes and observed a $V_{\mathrm{E}}$ increase due to an increase in $\mathrm{V}_{\mathrm{T}}$ while the $f$ remained unchanged. The difference in $f$ variation may be due to the type of exercise performed by our subjects, i.e. combing hair with alternating unsupported arm elevation, which is more difficult than static arm elevation. Younes and Kivinen ${ }^{25}$ also reported that, at low levels of exercise, ventilation increases primarily due to increases in $\mathrm{V}_{\mathrm{T}}$ and, at higher levels of exercise, the changes occur through changes in $f$. Tobin et al. ${ }^{23}$ reported that mean inspiratory flow reflects respiratory center drive input, which explains the increase in the $\mathrm{V}_{\mathrm{T}}$ /Ti ratio during unsupported arm elevation and its stabilization by the $3^{\text {rd }}$ minute with $58 \%$ of rest value.

When we analyzed the PhAng, we observed that the subject presented a value of $23.82^{\circ}$ at the end of the activity that corresponds to a $129 \%$ increase when compared with rest. This demonstrates an increase in RC-AB asynchrony. To our knowledge, there are no reports in the literature of PhAng values for healthy adults during unsupported arm elevation. With regard to rest values, our results were comparable with those found by Tobin et al. ${ }^{26}$ and Bloch et al. ${ }^{27}$ with healthy subjects during quiet breathing.

The variables PhRIB, PhREB and PhRTB represent the time percentage during a respiratory cycle in which the $\mathrm{RC}$ and the $\mathrm{AB}$ move in opposite directions. If both compartments move in the same direction along a respiratory phase (inspiratory, expiratory or both), a $0 \%$ value is computed. If the compartments move in opposite directions, a $100 \%$ value is computed ${ }^{20}$. In the present study, there was a progressive increase in PhRIB, PhREB and PhRTB, representing an increase of approximately $18 \%$ when comparing rest and the last minute of activity.

In healthy subjects, arm elevation leads to increased ventilatory and metabolic demands similar to mild exercise. At rest, the diaphragm is the dominant active inspiratory muscle, displacing the abdomen. During exercise, the inspiratory accessories are progressively recruited to assist the diaphragm and elevate the RC. During arm elevation, some of the upper torso muscles become involved in arm positioning, their participation in ventilation is decreased, and there is a shift of ventilatory work to the diaphragm. This disproportionate increase in diaphragmatic work contributes to the generation of ventilatory pressures ${ }^{3}$. These changes in $\mathrm{RC}$ and/or $\mathrm{AB}$ mechanics may be the cause of the increase in asynchrony in COPD patients and, to a small degree, in healthy subjects. However, COPD patients have insufficient diaphragmatic function, leading to considerable thoracoabdominal asynchrony.

In a study that assessed healthy subjects, Tobin et al. ${ }^{26}$ concluded that thoracoabdominal asynchrony and paradox in compartmental contribution to $\mathrm{V}_{\mathrm{T}}$ are predominantly due to 
increases in respiratory load rather than muscle fatigue. In the present study, the $\mathrm{RC}$ and $\mathrm{AB}$ movements at rest were similar to those reported by Tobin et al. ${ }^{23}$. It appears that the slight increase in the $\mathrm{AB}$ contribution in activity in exchange for $\mathrm{RC}$ contribution at rest is related to the arm elevation and to a greater participation of the diaphragm in ventilation. According to Goldman et al. ${ }^{28}$, abdominal wall displacement is intimately related to diaphragm displacement, however the same cannot be said for RC displacement.

The changes in the respiratory pattern mentioned above seem to be related to the hypothesis raised by many authors ${ }^{1,3,4,6}$ when referring to an increase in diaphragm activity in tasks involving unsupported arms, which may suggest an increase in diaphragmatic work to generate $\mathrm{V}_{\mathrm{T}}$ due to a decrease in participation of the accessory muscles needed to stabilize the shoulder girdle during unsupported arm movements. Tobin et al. ${ }^{23}$ reported that, although there was a slight predominance of $\mathrm{AB}$ contribution to $\mathrm{V}_{\mathrm{T}}$ compared to $\mathrm{RC}$ contribution in healthy subjects in the supine position, there was a large individual variation in the respiratory pattern at rest. Sharp et al. ${ }^{29}$, in their study on the sitting position at rest, reported that the RC was responsible for about $70 \%$ of $\mathrm{V}_{\mathrm{T}}$ whereas, in the supine position, its contribution was only about $25 \%$. Grimby, Bunn and Mead $^{30}$ also reported a $25 \%$ contribution of $A B$ to $V_{T}$ in individuals sitting on a cycle ergometer without exercising. These findings were attributed to the position of the legs with a tonic contraction of the muscles in the torso and abdominal wall that could effectively reduce abdominal compliance.

Grimby, Bunn and Mead $^{30}$ noted the variability of $V_{T}$ during exercise and the need for caution when analyzing the estimated changes to $\mathrm{RC}$ and $\mathrm{AB}$ contribution to $\mathrm{V}_{\mathrm{T}}$. However, they reported that, although there is a large individual variation, there appears to be a consistent pattern of changes in relative $\mathrm{RC}$ and $\mathrm{AB}$ movements with an increase in $\mathrm{V}_{\mathrm{T}}$ between rest and moderate exercise with a tendency toward a greater $\mathrm{AB}$ contribution to $\mathrm{V}_{\mathrm{T}}$. In contrast, when exercise intensity increases, there is an increase in $\mathrm{RC}$ contribution.

In the present study, for the calibration of RIP, the QDC was used during natural breathing, a procedure first described by Sackner et al. ${ }^{16}$ in 1989. This method computes the calibration factor $(\mathrm{K})$ by considering breaths of constant $\mathrm{V}_{\mathrm{T}}{ }^{31}$. In 2001, De Groote, Paiva and Verbandt ${ }^{31}$ criticized the QDC calibration method for the possibility of error when there is a variation in $\mathrm{V}_{\mathrm{T}}$ during the procedure. It should be noted that, in the present study, there was variation in $\mathrm{V}_{\mathrm{T}}$, but this occurred mainly during the exercise. During the calibration performed at rest, there was a slight variation in $\mathrm{V}_{\mathrm{T}}$ in 13 evaluated subjects, with maximum standard deviation of $12.2 \mathrm{~mL}$ (1.98\% $\mathrm{V}_{\mathrm{T}}$ variation).
Furthermore, this is the current method employed by various studies that used RIP to assess the respiratory pattern ${ }^{18,19,32-35}$.

Regarding surface EMG, we observed a steady increase in the amplitude of SCM muscle recruitment between rest and activity. These changes suggest an increase in SCM muscle participation in upper limb support during activities with unsupported arm elevation, reducing its respiratory function. This would lead to an increase in $\mathrm{AB}$ contribution to $\mathrm{V}_{\mathrm{T}}$ during exercise.

Our findings are comparable with those reported by Martinez, Couser and Celli ${ }^{8}$, who observed changes in respiratory muscle recruitment pattern indicating a more effective contraction of the diaphragm and an increase in SCM muscle amplitude of activation in EMG during activities with unsupported arm elevation. This suggests that some RC muscles are recruited during arm elevation. The present study also shows that there was an increase in $\mathrm{V}_{\mathrm{T}}$ and $f$ with a subsequent increase in $V_{E}$ during the activity with unsupported arm elevation, and there was an increase in $\mathrm{V}_{\mathrm{T}} / \mathrm{Ti}$ as the activity progressed, which shows a greater neural activation during exercise. We also observed an increase in thoracoabdominal asynchrony during unsupported arm elevation as well as an abrupt increase in SCM muscle amplitude of activation in the beginning of the exercise, showing a steady increase until the $5^{\text {th }}$ minute of activity.

The changes detected in the respiratory pattern and the EMG activity of the respiratory accessory muscle of the healthy subjects during the studied ADL can contribute to elucidate the determinants of dyspnea in patients with COPD. However, no reports of a normative parameter were found in the literature. Therefore, it was necessary to study how these variables behave in healthy subjects. Considering the findings of the present study, it is possible to use this data as normality parameters for clinical application to assess upper limb ADLs in patients with COPD.

\section{Study limitations}

Although the sample number was calculated in the pilot study to find significant differences between the moments (rest and activity), the number of subjects was insufficient for the correlations between respiratory pattern variables, thoracoabdominal motion and SCM muscle EMG. For the variables $\mathrm{RC} / \mathrm{V}_{\mathrm{T}}$ and $\mathrm{AB} / \mathrm{V}_{\mathrm{T}}$, although the sample calculated to a power of $80 \%$ was small (eight), after the statistical analysis, the power found by ANOVA was low.

Partially funded by Conselho Nacional de Desenvolvimento Científico e Tecnológico (CNPq) and Fundação de Amparo à Pesquisa do Estado de Minas Gerais (FAPEMIG), Brazil. 


\section{References $: \because 8$.}

1. Celli B, Criner G, Rassulo J. Ventilatory muscle recruitment during unsupported arm exercise in normal subjects. J Appl Physiol. 1988;64(5):1936-41

2. Baarends EM, Schols AMWJ, Slebos DJ, Mostert R, Janssen PP, Wouters EF. Metabolic and ventilatory response pattern to arm elevation in patients with COPD and healthy age-matched subjects. Eur Respir J. 1995;8(8):1345-51.

3. Couser JI Jr, Martinez FJ, Celli BR. Respiratory response and ventilatory muscle recruitment during arm elevation in normal subjects. Chest. 1992;101(2):336-40.

4. Criner GJ, Celli BR. Effect of unsupported arm exercise on ventilatory muscle recruitment in patients with severe chronic airflow obstruction. Am Rev Respir Dis. 1988;138(4):856-61.

5. Dodd DS, Brancatisano T, Engel LA. Chest wall mechanics during exercise in patients with severe chronic air-flow obstruction. Am Rev Respir Dis. 1984;129(1):33-8.

6. Epstein SK, Celli BR, Williams J, Tarpy S, Roa J, Shannon T. Ventilatory response to arm elevation. Its determinants and use in patients with chronic obstructive pulmonary disease. Am J Respir Crit Care Med. 1995;152(1):211-6.

7. Martinez FJ, Couser JI, Celli BR. Factors influencing ventilatory muscle recruitment in patients with chronic airflow obstruction. Am Rev Respir Dis. 1990;142(2):276-82.

8. Martinez FJ, Couser JI, Celli BR. Respiratory response to arm elevation in patients with chronic airflow obstruction. Am Rev Respir Dis. 1991;43(3):76-80.

9. Velloso M, Stella SG, Cendon S, Silva AC, Jardim JR. Metabolic and ventilatory parameters of four activities of daily living accomplished with arms in COPD patients. Chest. 2003;123(4): 1047-53.

10. Celli BR, Rassulo J, Make BJ. Dyssynchronous breathing during arm but not leg exercise in patients with chronic airflow obstruction. N Engl J Med. 1986;314(23):1485-90.

11. Dolmage TE, Maestro L, Avendano MA, Goldstein RS. The Ventilatory response to arm elevation of patients with chronic obstructive pulmonary disease. Chest. 1993;104(4):1097-100.

12. Gigliotti F, Coli C, Bianchi R, Grazzini M, Stendardi L, Castellani C, et al. Arm exercise and hyperinsuflation in patients with COPD. Chest. 2005;128(3):1225-32.

13. Pereira CAC. Espirometria. J Pneumol. 2002;28 (Suppl 3 ):1-82.

14. Pereira CAC, Barreto SP, Simões JG, Pereira FQL, Gerstler JG, Nakatani J. Valores de referência para espirometria em uma amostra da população brasileira adulta. J Pneumol. 1992;18(1): 10-22.

15. Konno K, Mead J. Measurement of separate volume changes of the rib cage and abdomen during breathing. J Appl Physiol. 1967;22(3):407-22.

16. Sackner MA, Watson H, Belsito AS, Feinerman D, Suarez M, Gonzalez G, et al. Calibration of respiratory inductive plethysmograph during natural breathing. J Appl Physiol. 1989;66(1): 410-20.

17. Bloch KE, Barandun J, Sackner MA. Effect of mouthpiece breathing on cardiorespiratory response to intense exercise. Am J Respir Crit Care Med. 1995;151(4):1087-92.

18. Parreira VF, Tomich GM, Britto RR, Sampaio RF. Assessment of tidal volume and thoracoabdominal motion using volume and flow-oriented incentive spirometers in healthy subjects. Braz J Med Biol Res. 2005;38(7):1105-12.
19. Parreira VF, Coelho EM, Tomich GM, Alvim AMA, Sampaio RF, Britto RR. Avaliação do volume corrente e da configuração toracoabdominal durante 0 uso de espirômetros de incentivo a volume e a fluxo, em sujeitos saudáveis: influência da posição corporal. Rev Bras Fisioter. 2004;8(1):45-51.

20. Reber A, Geiduschek JM, Bobbia SA, Bruppacher HR, Frei FJ. Effect of continuous positive airway pressure on the measurement of thoracoabdominal asynchrony and minute ventilation in children anesthetized with sevoflurane and nitrous oxide. Chest. 2002;122(2):473-8.

21. Falla D, Dall'Alba P, Rainoldi A, Merletti R, Jull G. Location of innervation zones of sternocleidomastoid and scalene muscles-a basis for clinical and research electromyography applications. Clin Neurophysiol. 2002;113(1):57-63

22. Falla D, Dall'Alba P, Rainoldi A, Merletti R, Jull G. Repeatability of surface EMG variables in the sternocleidomastoid and anterior scalene muscles. Eur J Appl Physiol. 2002;87(6):542-9.

23. Tobin MJ, Chadha TS, Jenouri G, Birch SJ, Gazeroglu HB, Sackner MA. Breathing patterns. 1 Normal subjects. Chest. 1983;84(2):202-5.

24. Feltrin M. Estudo do padrão respiratório e da congiguração tóraco-abdominal em indivíduos normais, nas posições sentada, dorsal e laterais, com o uso de pletismografia respiratória por indutância [dissertação]. São Paulo: Unifesp; 1994.

25. Younes M, Kivinen G. Respiratory mechanics and breathing pattern during and following maximal exercise. J Appl Physiol. 1984;57(6):1773-82.

26. Tobin MJ, Perez W, Guenther SM, Lodato RF, Dantzker DR. Does rib cage-abdominal paradox signify respiratory muscle fatigue? J Appl Physiol. 1987;63(2):851-60.

27. Bloch KE, Li Y, Zhang J, Bingisser R, Kaplan V, Weder W, et al. Effect of surgical lung volume reduction on breathing patterns in severe pulmonary emphysema. Am J Respir Crit Care Med. 1997;156(2 Pt 1):553-60.

28. Goldman MD, Grassino A, Mead J, Sears TA. Mechanics of the human diaphragm during voluntary contraction: dynamics. J Appl Physiol. 1978;44(6):840-8.

29. Sharp JT, Goldberg NB, Druz WS, Danon J. Relative contributions of rib cage and abdomen to breathing in normal subjects. J Appl Physiol. 1975;39(4):608-18.

30. Grimby G, Bunn J, Mead J. Relative contribution of rib cage and abdomen to ventilation during exercise. J Appl Physiol. 1968;24(2):159-66.

31. De Groote A, Paiva M, Verbandt Y. Mathematical assessment of qualitative diagnostic calibration for respiratory inductive plethysmography. J Appl Physiol. 2001;90(3):1025-30.

32. Tomich GM, Franca DC, Diorio AC, Britto RR, Sampaio RF, Parreira VF. Breathing pattern, thoracoabdominal motion and muscular activity during three breathing exercises. Braz J Med Biol Res. 2007;40(10):1409-17.

33. Brant TCS, Parreira VF, Mancini MC, Becker HMG, Reis AFC, Britto RR. Padrão respiratório movimento toracoabdominal de crianças respiradoras orais. Rev Bras Fisioter. 2008;12(6):495-501.

34. Teramoto S, Fukuchi Y, Nagase T, Matsuse T, Orimo H. A comparison of ventilation components in young and elderly men during exercise. J Gerontol A Biol Sci Med Sci. 1995;50(1):B34-9.

35. Brown K, Aun C, Jackon E, Mackersie A, Hatch D, Stocks J. Validation of respiratory inductive plethysmography using the Qualitative Diagnostic Calibration method in anaesthetized infants. Eur Respir J. 1998;12(4):935-43. 